\title{
Simulating the hydrological response of a small tropical forest watershed (Mata Atlantica, Brazil) by the AnNAGNPS model
}

\author{
Demetrio Antonio Zema a , Manuel Esteban Lucas-Borja b,*, Bruno Gianmarco Carrà a , Pietro Denisi a , \\ Valdemir Antonio Rodrigues ${ }^{c}$, Mauricio Ranzini ${ }^{\mathrm{d}}$, Francisco Carlos Soriano Arcova ${ }^{\mathrm{d}}$, \\ Valdir de Cicco ${ }^{\mathrm{d}}$, Santo Marcello Zimbone ${ }^{\mathrm{a}}$ \\ a Department “Agraria”, University “Mediterranea” of Reggio Calabria, Località Feo di Vito, I-89122 Reggio Calabria, (Italy) \\ b Departamento de Ciencia y Tecnología Agroforestal y Genética, Universidad de Castilla La Mancha, Campus Universitario s/n, C.P. 02071 Albacete, (Spain) \\ c Departamento de Ciência Florestal da Faculdade de Ciências Agronômicas, Universidade Estadual Paulista, FCA - UNESP, Botucatu, São Paulo, (Brazil) \\ ${ }^{d}$ Instituto Florestal, Governo do Estado de São Paulo, São Paulo, (Brazil)
}

\section{H I G H L I G H T S}

- The runoff prediction capability of AnnAGNPS became satisfactory at annual, seasonal and monthly scales.

- The availability of water can be attributed mainly to groundwater reserves.

- The evapo-transpiration of forest trees plays an important role in the hydrological balance

- The study has demonstrated the basic hydrological role of vegetation in water balance of tropical forest.

\section{G R A P H I C A L A B S T R A C T}

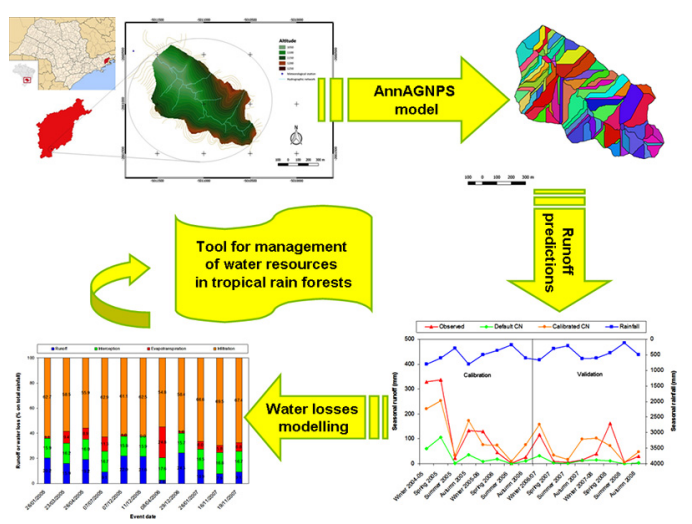

\section{A R T I C L E I N F O}

\section{Article history:}

Received 23 February 2018

Received in revised form 23 April 2018

Accepted 24 April 2018

Available online 1 May 2018

Editor: D. Barcelo

\section{Keywords:}

Hydrological cycle

Water balance

Model calibration

Evapo-transpiration

Canopy interception

Tropical forest

\begin{abstract}
A B S T R A C T
Given the intrinsic hydrological cycle made of large input of water vapour and intense precipitation producing large volumes of water and sediment, modelling runoff and water losses in humid tropical watersheds is important for forest and water resources management. For instance, reliable simulations of the water cycle in such environments are a prerequisite for predictions of water quality, soil erosion and the climate change effects on water resources. The distributed parameter, physically based, continuous simulation, daily time step AnnAGNPS model, was implemented in almost completely forested ( $98 \%$ of its area, $\left.0.56 \mathrm{~km}^{2}\right)$ Cunha watershed (Brazil) to assess its capability to simulate hydrological processes under tropical conditions. The simulated surface runoff was compared to 4 -year observations with statistical indices on several time scales. The model, running with default $\mathrm{CN}$ of forest, showed poor predictions of runoff. After increasing $\mathrm{CN}$ from 63 to 72 by calibration, the runoff prediction capability of AnnAGNPS was satisfactory on annual, seasonal and monthly scales, while daily runoff predictions were less accurate. Modelling water losses at event scale showed that the effect of forest vegetation on water retention during a single precipitation was more limited than for longer periods (months, seasons and years), since evapo-transpiration and interception account for small shares $(>20 \%)$ of total precipitation.
\end{abstract}

\footnotetext{
* Corresponding author.

E-mail address: manuelesteban.luca@uclm.es (M.E. Lucas-Borja).
} 
This study demonstrated that the AnnAGNPS model has reliable runoff prediction capacity in tropical forest watersheds at the annual and seasonal scales $(E>0.73)$, whereas daily runoff simulations are less accurate $(E=0.44)$. The use of this model may prove an important tool for water resource and territory management in tropical rainforests.

(C) 2018 Published by Elsevier B.V.

\section{Introduction}

Tropical forests are the richest terrestrial ecosystems in biodiversity and structural complexity terms, and perform important ecological functions, such as climatic regulation, water and nutrient cycling, maintenance of biodiversity and reducing of greenhouse gas emissions, among others (Whitmore, 1990). Tropical forests are essential for maintaining the ecological integrity of rivers and their associated watersheds (Ataroff and Rada, 2000; Neill et al., 2001). In these environments the Atlantic Forest is the most threatened biome in Brazil (SOS Atlantic Forest and INPE, 2013). As Silvano et al. (2005) stated, land use practices that reduce riparian forest cover have several impacts on streams, such as the increased sediment load and nutrient enrichment due to runoff. Therefore for tropical forests, and especially for Brazilian Atlantic forests where data on climate and runoff is scarce (especially for Mata Atlantica, Fujieda et al., 1997; Rodrigues et al., 2017; Marmontel et al., 2018), water balance evaluations are a prerequisite to understand key hydrologic cycle processes. The watersheds of humid tropical zones are characterised by large energy inputs in the form of fluxes of water vapour from mid latitudes, intense and constant precipitation, rapid weathering of inorganic and organic matter, and the rapid introduction of large volumes of water and sediment (Wohl et al., 2012). One of the main characteristics of tropical ecosystems is the intra-annual variability of precipitation and this, in conjunction with land use, can strongly affect a basin's hydrological regime (Liu et al. 2014; Shi et al. 2013; Viola et al., 2014).

The hydrologic cycle is used to model the storage and movement of water between different layers of the Earth, such as biosphere, atmosphere, lithosphere and hydrosphere. Rapidly changing climate and land use management may place the water-related functions of forests at risk. In this context, simulation tools able to accurately predict the hydrological behaviour of tropical forests are necessary. If these tools are available and their use is reliable, the future management of tropical forests and water resources may be more easily targeted to their conservation and valorisation.

An integrated approach is vital for successful watershed ecosystems management (Verstraeten et al., 2003). Computer-based hydrologic models are essential tools for water resource planning, development and management because they enable long-term simulations of the effects of watershed processes and management activities (Singh and Woolhiser, 2002). The evaluation of best management practices has also been facilitated by watershed hydrologic models (Arabi et al., 2006; Douglas-Mankin et al., 2010). A number of watershed-scale models with components able to simulate water runoff, soil erosion and sediment and pollutant transport have been developed that vary in complexity and data input requirement terms (Borah and Bera, 2004). However, when hydrological and geomorphological data are scarce, which is the case of Brazilian watersheds, it is unfeasible to apply a complex hydrologic model that is driven by large amounts of data (Beskow et al., 2011).

Among the available hydrological models on the watershed scale, AnnAGNPS and SWAT use the SCS-TR 55 method for runoff calculations (SCS, 1986), which is a suitable approach in poor-data environments. The basic principles of AnnAGNPS are similar to those of SWAT, but best management practices simulations appear to be the strength of AnnAGNPS (Srivastava et al., 2002). Thus this latter model is more advisable for the future planning of watersheds. The AnnAGNPS model combines the advantages of GIS (Geographic Information Systems) data processing with the physical characterisation of watersheds by offering modelling opportunities for ungauged areas that have limited data and prohibit using models that rely on calibration to obtain input variables (Shamshad et al., 2008). The model has been successfully used in many areas of the world in recent years, including Spain (Chahor et al., 2014; Taguas et al., 2009; Zema et al., 2016), Nepal (Shrestha et al., 2006), Italy (Licciardello et al., 2007), Belgium (Zema et al., 2012), Czech Republic (Kliment et al., 2008), India (Sarangi et al., 2007), Australia (Baginska et al., 2003), Malaysia (Shamshad et al., 2008), Canada (Das et al., 2006), USA (Polyakov et al., 2007; Parajuli et al., 2009; Yuan et al., 2008; Pease et al., 2010) and China (Liu et al., 2008; Hua et al., 2012). These studies evaluated the ability of the AnnAGNPS model to predict runoff, sediment and pollutant loadings under different climate and land use conditions in various watersheds with areas ranging from 0.1 to $2500 \mathrm{~km}^{2}$. Conversely, and as far as the authors know, no AnnAGNPS applications in watersheds of tropical forests, such as Brazilian Atlantic biomes, are used to model runoff generation and other hydrological processes. Very few works conducted under tropical conditions exemplify the difficulty in obtaining the appropriate number of parameters needed in the calibration of this model, especially in Brazil, where these data types are scarce (De Mello et al., 2016; Marmontel et al., 2018). Moreover in Brazil, these studies have taken into account large basins (Viola et al., 2014), and have thus neglected smaller watersheds, where instead research has provided some of the most important insights into hydrological functions in forest ecosystems (Neill et al., 2006). In many watersheds in Brazil, streamflow data are less commonly available than rainfall records. Quantitative assessments of streamflow by rainfall-runoff models have not been made, and have left serious problems with land-use change and its effects on water resource management to one side (Beskow et al., 2011).

In a small watershed (Cunha, Brazil), taken as a case study, this paper aims to evaluate: (i) the accuracy of the AnnAGNPS model in simulating the hydrological response of Brazilian Atlantic tropical forests by default input parameters using a 4-year database of observations; (ii) the possibility to improve the model's runoff prediction capacity through calibration; (iii) propose the resulting value of calibrated Curve Numbers for tropical forests; (iv) if the model proves reliable under the experimental conditions, the amounts of different water losses (e.g., infiltration, evapo-transpiration, interception) in tropical forests, as predicted by AnnAGNPS on the daily scale.

If the applicability and reliability of this model are verified by the calibration/validation activity of this study on the different time scales (annual, seasonal, monthly and daily), AnnAGNPS may help land managers to adopt strategic choices to manage water resources and predict the hydrological effects of climate change on tropical forest watersheds in Brazil.

\section{Materials and methods}

\subsection{Study area}

The Cunha watershed (Fig. 1a) is located in the Parque Estadual da Serra do Mar (Cunha Municipality, Sao Paulo State, Brazil). The study area consists of a mountain plateau of 1000-1200 m altitude, and the headwater area of the Paraiba Valley (East Atlantic region). The region is covered with the Mata Atlantica (rainforest of the Serra do Mar mountain chain). This latter is one of the most typical areas of Atlantic forest. 

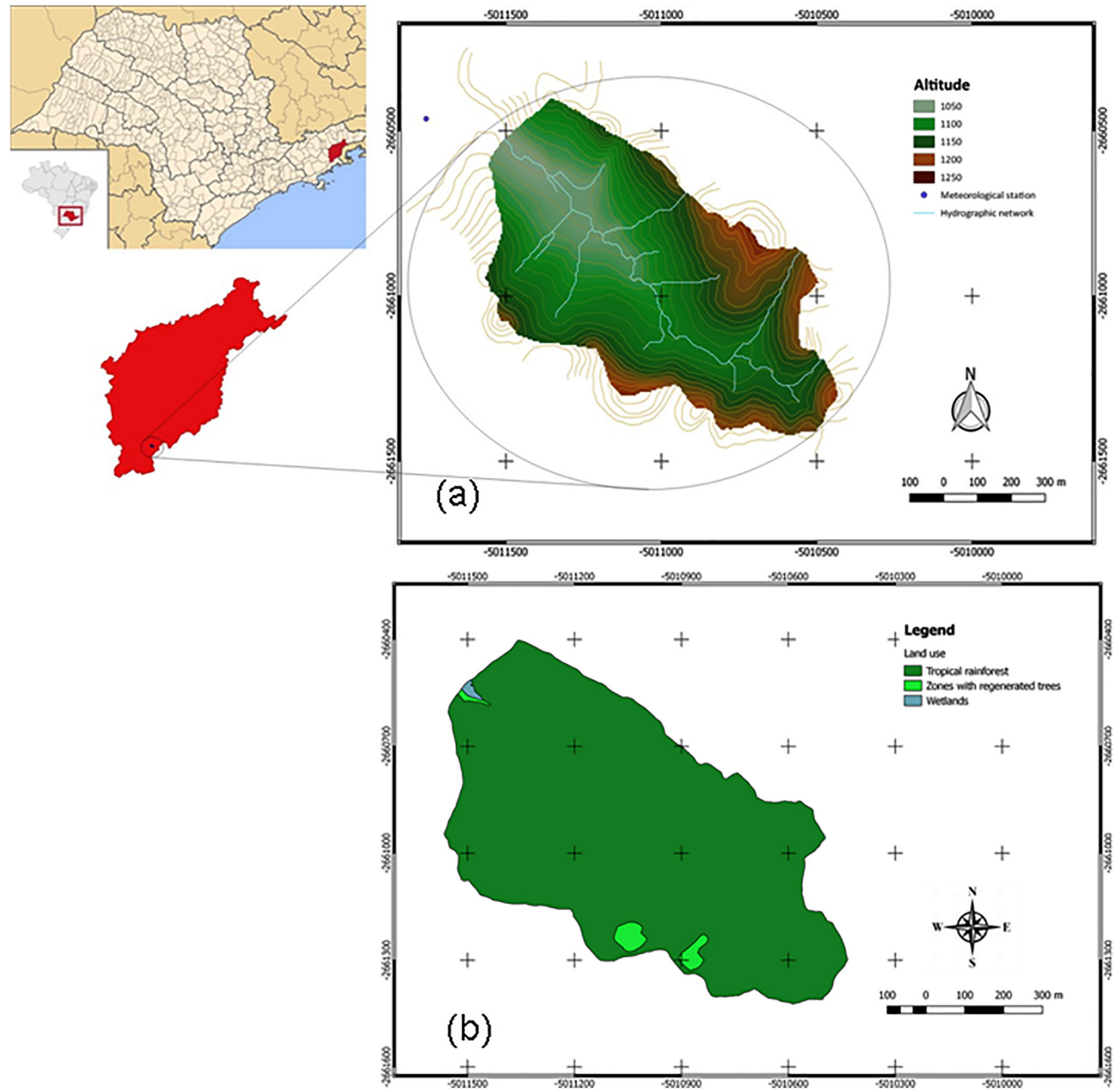

Fig. 1. - Geographical location (a) and land use map (b) of the Cunha watershed (Brazil).

Its importance lies in the conservation of biodiversity and endemic species from endanger (Galindo-Leal and Câmara, 2005).

\subsubsection{Morphometry}

The Cunha watershed $\left(0.56 \mathrm{~km}^{2}\right)$ is a tributary of the Paraibuna river which, in turn, flows into the main Paraíba do Sul river. The examined watershed covers an area characterised by steep hillslopes (mean slope of $46 \%$ ). The main channel (whose mean slope is $14 \%$ ) rises at $1220 \mathrm{~m}$ a.s.l. and flows after $1.5 \mathrm{~km}$ into the Paraibuna river (outlet coordinates $23^{\circ} 14^{\prime} 06^{\prime \prime} \mathrm{S}, 45^{\circ} 01^{\prime} 17^{\prime \prime} \mathrm{W}$ ) at a height of $1050 \mathrm{~m}$ (Fig. 1a). The drainage density is $2.8 \mathrm{~km} \mathrm{~km}^{-2}$ and the form factor is 0.35 . The concentration time (the time required by runoff to reach the closure section from the farthest hydraulically distant point, Chow et al., 1988), estimated according to Kirpich (1940), is $0.20 \mathrm{~h}$.

\subsubsection{Climate and hydrology}

Climate, according to the Köppen classification, is Cwa, which is a humid subtropical climate with precipitation in all seasons (the maximum occurring in summer) and dry winters. The average annual rainfall is about $2.200-2.300 \mathrm{~mm}$. The average annual temperature is 19.1 ${ }^{\circ} \mathrm{C}$; August is the driest month and January is the wettest. The average evapo-transpiration, $682 \mathrm{~mm}_{\text {year }}{ }^{-1}$, is mainly plant transpiration as soil evaporation is largely negligible in this forest (Fujieda et al., 1997). Winds are damp with predominant South-East (SE) and SouthSouth-East (SSE) directions, laden with moisture and often bringing 
low clouds, fog or drizzle. As response to meteorological stress, the water course shows a constant hydrological regime, which is typical of tropical water courses.

\subsubsection{Land use and soil}

The main land use in the watershed is tropical rain forest (98\% of the total area), characterised by an evergreen cover with a uniform canopy reaching $20 \mathrm{~m}$ and emerging trees up to $40 \mathrm{~m}$ (according to surveys by the Brazilian Institute of Geography and Statistics, IBGE) (Fig. 1b). Forest is dense shrubbery composed of nanofanerophytes and Cyatheaceae (which mainly includes Pteridophyta, similar to ferns), and dominant plants consisting of Araucaria angustifolia (Bertol.), arboreal ferns (Cyathea delgadii) and palm trees (Euterpe edulis). As logging has occurred for over 50 years in the region, secondary vegetation is undergoing a recovery process (Aguiar et al., 2001). According to the floristic survey in the watershed, it has 168 species, 89 genera, and 47 families. The most predominant families are Lauraceae, Melastomataceae, Myrtaceae, Solanaceae and Asteraceae. Of the surveyed species, $28 \%$ are pioneers, $20 \%$ early secondary, $39 \%$ late secondary, and $13 \%$ climax, which have been considered a recovery area with a high diversity of communities and habitats (Aguiar et al., 2001).

As regards other minor land uses, zones with regenerated trees represent $1.8 \%$ of the watershed surface, while wetlands cover only $0.2 \%$ (Fig. 1b).

According to the taxonomic classification of the IBGE, the main soil in the Cunha watershed is CX3 type (CX Tb Dystrophic + LVA Dystrophic), Cambisol and red-yellow Latosol. Soil texture is classified as sandy clay loam ( $67.0 \%$ of sand, $6.5 \%$ of silt and $26.5 \%$ of clay, JICA, 1980 ) and saturated hydraulic conductivity is about $5 \times 10^{-2} \mathrm{~mm} \mathrm{~s}^{-1}$.

\subsection{Hydrological characterisation}

Meteorological data derive from records of a meteorological station (Meteodata model), located close to the watershed outlet (200 $\mathrm{m}$ downstream) at $1045 \mathrm{~m}$ a.s.l., and equipped with a rain gauge, a hygrothermograph, a pyranometer, a weather vane and an anemometer.

Discharge data were continuously measured at the watershed outlet for the same observation period by an ultrasonic flow meter (WR-11Z model, NAKAASA corporation, precision $0.5 \mathrm{~cm}$ ), operating over a spillway of an open trapezoidal channel ( $20 \mathrm{~m}$ long, $0.9 \mathrm{~m}$ large and $2 \mathrm{~m}$ high, with 1:1 sloping walls, Fig. 2). The water depth ("h", cm) was converted into discharge ("q", $\mathrm{L} \mathrm{s}^{-1}$ ) by the following equation, purposely

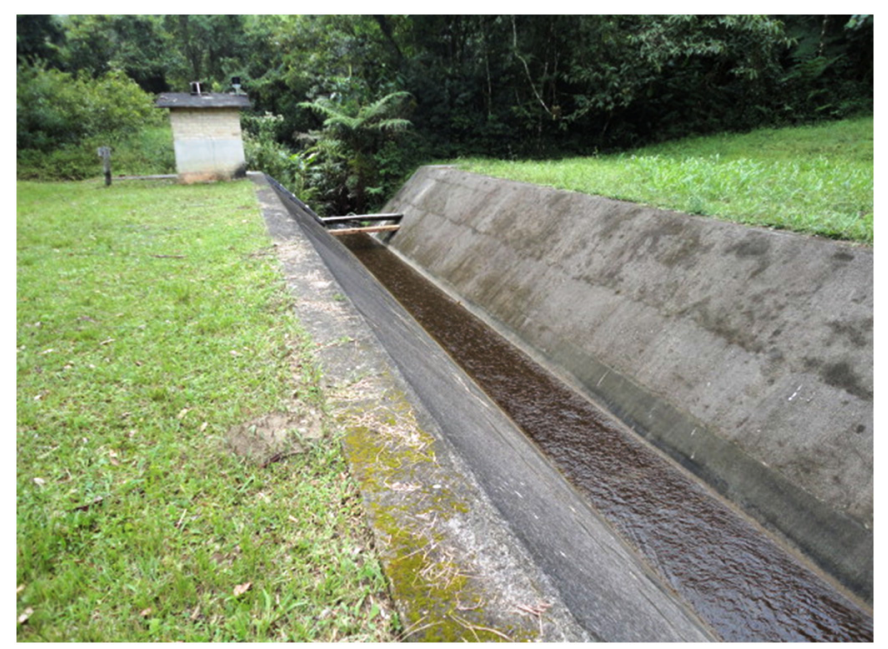

Fig. 2. - Hydrometric gauging station in the Cunha watershed (Brazil). calibrated by couples of simultaneous depth and discharge measures $\left(r^{2}=0.998\right)$ (Cicco et al., 1987):

$\mathrm{q}=2.915 * \mathrm{~h}^{1.698}$

The daily runoff volume was estimated (in $\mathrm{mm}$ ) from the measured discharge.

Precipitation and runoff volumes were measured in four hydrological years (October 2004 to September 2008) and then aggregated on monthly, seasonal (summer, from December to February, spring, from March to May, winter, from June to August, and autumn, from September to November) and annual scales. The following statistics were calculated for the observation period: mean, standard deviation, minimum, maximum and coefficient of variation (CV). The hydrological response of the watershed was quantified by the runoff coefficient, which was calculated on the seasonal and monthly scales according to the cumulative precipitation/corresponding runoff volume ratio. The analysis was not extended to the annual scale due to the small number of observation years.

\subsection{Hydrological modelling}

\subsubsection{The AnnAGNPS model}

AnnAGNPS (Geter and Theurer, 1998; Bingner and Theurer, 2005) is a distributed parameter, physically based, continuous simulation daily time step model developed in 1998 by the ARS and NCRS services of USDA. The model simulates runoff, sediment, and pollutants transported through the channel system to the watershed outlet.

Model implementation requires watershed physical information as the input climate data, as well as crop, and other land uses, plus irrigation management data. As climate information, daily precipitation, maximum and minimum temperatures, dew point temperatures, sky cover, and wind speed are necessary. The watershed is divided into user-specified homogeneous drainage areas by taking into account the spatial variability of soils, land use, topography and climatic conditions. The model's basic components include hydrology, sedimentation and chemical transport. The hydrologic submodel uses the SCS curve number technique (USDA, 1972) to simulate surface runoff on a daily scale, based on a continuous soil moisture balance. The model only requires initial values of curve number $(\mathrm{CN})$ to be taken from the related tables of the USDA-SCS manual based on the hydrological group, cover type, treatment and hydrological condition of soil for antecedent moisture conditions (AMC). AnnAGNPS is able to update the daily soil moisture balance, and also according to the crop cycle and change according to the CN parameter. The runoff in channels is calculated by Manning's equation.

\subsubsection{Model implementation and evaluation}

A 5-m resolution Digital Elevation Model (DEM, built from a topographical map on a scale of 1:10.000 with contour lines every $5 \mathrm{~m}$; error of $0.25 \mathrm{~mm}$ ) was used to generate the watershed topography. By applying the GIS interface of AnnAGNPS to the produced DEM, the watershed was discretised into homogeneous drainage areas ("cells") and its hydrographic network was segmented into channels ("reaches"). The values of CSA (Critical Source Area) and MSCL (Minimum Source Channel Length), which control watershed and channel network reproduction in AnnAGNPS, were set at 0.5 ha and $6 \mathrm{~m}$. The model reproduced 104 cells (with areas between 0.003 and 2.63 ha) and 50 reaches. Then the prevalent land use and soil type were associated by the same interface with each cell (Fig. 3).

Soil parameters were taken from the Brazilian soil map prepared by IBGE in 2001. Clay soil with a uniform profile (up to a depth of $1 \mathrm{~m}$ ) and three land uses (tropical rain forest, zones with regenerated trees and wetlands, derived from field surveys) were assumed (Table 1 ). In the absence of direct measures of some hydrological soil parameters required by AnnAGNPS, saturated hydraulic conductivity $\left(\mathrm{K}_{\text {sat }}\right)$, wilting 

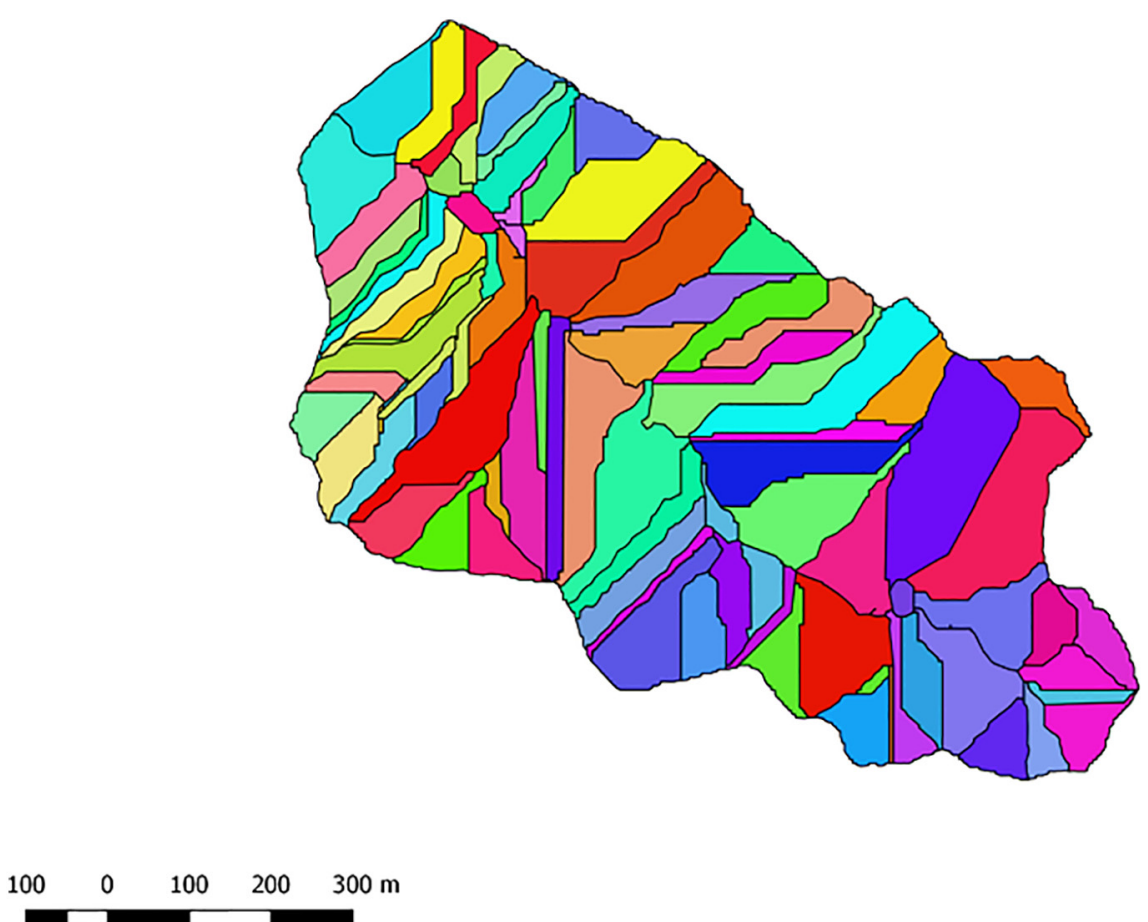

Fig. 3. - Layout of the Cunha watershed (Brazil) discretised in homogenous drainage areas ("cells") by the GIS interface of the AnnAGNPS model.

point and field capacity were estimated from the soil texture data by Rawls' methodology (1991). Given the estimated value of $\mathrm{K}_{\text {sat }}$, the hydrological group "B" for soil was chosen (USDA, 1972).

Climate data were provided by both the meteorological station and input into the AnnAGNPS climate subroutines (AnnAGNPS, 2001). Following Chow (1964), surface runoff was separated from baseflow by the linear method applied to the observed streamflow records.

The hydrological AnnAGNPS submodel was initially run with the default values of the initial Curve Numbers (CNs), according to the standard procedure set by USDA (1972) (Table 1). The adjustment of initial soil water storage was performed by appending the first 2 years (2003-2004) to the climate records beginning in January 2005.

The hydrological AnnAGNPS submodel was then calibrated by taking into account the most important input parameter to which runoff is sensitive (Yuan et al., 2001; Baginska et al., 2003). The split-sample technique (Klemes, 1986) was used to evaluate the runoff volume predicted by the model during the calibration and validation periods. More specifically, the 4 years of runoff observations available at the watershed's outlet were classified according to their Wetness Index (WI, Moisello, 1999): 2005 was the driest year (WI = 1.35), while 2007 was the wettest year (WI $=0.86)$; the WIs of 2006 and 2008

Table 1

Input parameters of soil to implement the AnnAGNPS model at the Cunha watershed (Brazil).

\begin{tabular}{llll}
\hline Soil parameter & Initial CN & Land use & Values \\
\hline Average sand content (\%) & & 67.0 \\
Average silt content (\%) & & 6.5 \\
Average clay content (\%) & & 26.5 \\
Field capacity $\left(\mathrm{m} \mathrm{m}^{-1}\right)$ & & 0.24 \\
Wilting point $\left(\mathrm{m} \mathrm{m}^{-1}\right)$ & & 0.16 \\
Hydrological group (USDA, 1972) & & $\mathrm{B}$ \\
Saturated hydraulic conductivity $\left(\mathrm{K}_{\text {sat, }}, \mathrm{mm} \mathrm{s}^{-1}\right)$ & & $5 \times 10^{-2}$ \\
Bulk density $\left(\mathrm{t} \mathrm{m}^{-3}\right)$ & & & 1.3 \\
Initial Curve Number (CN, - ) & Default & Forest & 50 \\
& & Regenerated trees & 60 \\
& \multirow{2}{*}{ Calibrated } & Forest & 72 \\
& & Regenerated trees & 66 \\
\hline
\end{tabular}

were 0.95 and 0.86 , respectively. Based on the WI values, one dry and one wet year were chosen for calibration (2005 and 2007, respectively) and the same was done for validation (2006 and 2008). This choice avoided a model evaluation being biased by too dry or too wet consecutive years, which would have happened if the first 2 years were adopted for calibration and the last 1 years for validation.

The default value of the initial CN (equalled 63) of the forested areas ( $>95 \%$ of the total watershed area) was modified until the best prediction capability of the AnnAGNPS model was obtained (Table 1). The calibration procedure stopped when the maximum coefficient of efficiency (E) value, according to Nash and Sutcliffe (1970), was achieved (see also Section 2.3.3)

The runoff prediction capability of AnnAGNPS was evaluated separately during the calibration (with both the default and calibrated values of the initial $\mathrm{CN}$ ) and the validation (with the calibrated $\mathrm{CN}$ ) periods on the seasonal (4 periods per year, i.e. 3 months per season), monthly and event scales; the annual scale was excluded by this analysis due to the small number of annual observations (two for the calibration and two for the validation periods). An evaluation of the calibrated model during the entire period (January 2005-December 2008) was also made (including the annual scale). Since erosion is one of the most negative effects of surface runoff (and may occur on steep hillslopes, like those that characterise the Cunha watershed), runoff was also simulated for the erosive rainfall (over $13 \mathrm{~mm}$, Wischmeier and Smith, 1978) of the observation period.

The runoff simulation results obtained by AnnAGNPS were analysed for "goodness-of-fit" with the observed data. To this end, the following were adopted: (i) a set of statistics (i.e. the maximum, minimum, mean and standard deviation of both the observed and simulated values); (ii) other evaluation criteria commonly adopted in the literature: coefficient of determination $\left(\mathrm{r}^{2}\right)$, coefficient of efficiency (E), and Coefficient of Residual Mass (CRM), as suggested by other authors (Willmott, 1982; Legates and McCabe, 1999; Krause et al., 2005; Loague and Green, 1991). The optimal values of these criteria, together with the equations for their calculations, are reported in the works of Zema et al. (2012), Moriasi et al. (2007) and Van Liew and Garbrecht (2003). 


\subsubsection{Analysis of the hydrological cycle by AnnAGNPS}

The water balance of the watershed was calculated by measuring or estimating the inlet water by rainfall, the surface runoff passing through the outlet, and the water lost through evapo-transpiration, interception, infiltration and basin storage on the ground.

The analysis of the hydrological cycle was carried out by evaluating the water losses in the sample of the erosive events of the experimental database, with differences lower than $20 \%$ found between the observed runoff volume and the corresponding prediction by AnnAGNPS. To this end, the runoff (R) and evapo-transpiration (ET) depths simulated by the calibrated model were considered. Since AnnAGNPS does not provide estimations of the precipitation shares intercepted by plant canopy cover (and the same applies to the water volumes stored in basins on the soil and infiltrates), the interception water losses (I, [mm]) in the forest areas were calculated using the formula proposed by Fujieda et al. (1997), which very accurately estimates $(r=0.97, n=67)$ the data of canopy interception measured on the event scale in the same watershed:

$I=0.603+0.144 \mathrm{P}$

where $P$ is the rainfall of the event [mm].

Finally, the water volumes stored in basins on the soil and infiltrates (F) were estimated as the difference between the rainfall and the sum of the other water losses throughout the event. Therefore, the equation that expresses the water balance of the watershed on the event scale is as follows:

$\mathrm{P}=\mathrm{R}+\mathrm{I}+\mathrm{ET}+\mathrm{F}[\mathrm{mm}]$

\section{Results}

\subsection{Hydrological characterisation of the watershed}

The analysis of the 4-year hydrological observations available in the Cunha watershed highlights that precipitation (1930 $\pm 261 \mathrm{~mm}$ per year, Table 2) was higher in summer (over $650 \mathrm{~mm}$ ) and lower in winter (about $220 \mathrm{~mm}$ ), while in spring (about $550 \mathrm{~mm}$ ) it was $18 \%$ less than in summer. As a direct effect of this meteorological input, the river flows ( $1671 \pm 404 \mathrm{~mm}$ per year, Table 2$)$ recorded in winter and spring ( $<280-300 \mathrm{~mm}$ on average) were about $40-50 \%$ less than in autumn and summer (about 480 and $550 \mathrm{~mm}$, respectively). The variability in the precipitation recorded throughout the observation period was noticeable in spring (CV of about 70\%) and lower in the other seasons (30-45\%); the CVs of seasonal runoff were lower (25-40\% for all seasons, except for spring, $C V=59.1 \%$ ). Thus river flow was more stable than precipitation (Table 3a).

As mentioned in the Materials and Methods section, the hydrological response of the watershed was synthetically expressed in runoff coefficient terms. On the seasonal scale the highest runoff coefficient $(1.43 \pm$ 0.78 ) was observed in winter, while in summer the runoff generation

Table 2

Measurements of precipitation $(\mathrm{P})$ and runoff $(\mathrm{Q})$ and estimations of potential evapotranspiration ( $\mathrm{ET}_{\mathrm{p}}$, by Thornthwaite's equation) and interception (I, by Eq. (2)) (October 2004 to September 2008) in the Cunha watershed (Brazil).

\begin{tabular}{llllll}
\hline Hydrological year & $\mathrm{P}(\mathrm{mm})$ & $\mathrm{Q}(\mathrm{mm})$ & $\begin{array}{l}\text { Runoff coefficient } \\
(\mathrm{mm})\end{array}$ & $\mathrm{ET}_{\mathrm{p}}(\mathrm{mm})$ & $\mathrm{I}(\mathrm{mm})$ \\
\hline $2004 / 05$ & 2317 & 2218 & 0.96 & 864 & 430 \\
$2005 / 06$ & 1851 & 1699 & 0.92 & 849 & 380 \\
$2006 / 07$ & 1796 & 1275 & 0.71 & 882 & 349 \\
$2007 / 08$ & 1756 & 1490 & 0.85 & 844 & 379 \\
Mean & 1930 & 1671 & 0.86 & 860 & 385 \\
Std. Dev. & 261 & 404 & 0.09 & 16.78 & 33.41 \\
CV & 13.51 & 24.18 & 10.97 & 1.95 & 8.59 \\
\end{tabular}

Table 3

Statistics of the hydrological observations (October 2004 to September 2008) on seasonal (a) and monthly (b) scales in the Cunha watershed (Brazil).

\begin{tabular}{|c|c|c|c|c|c|}
\hline & Min & Mean & Max & Std. Dev. & $\mathrm{CV}$ \\
\hline \multicolumn{6}{|c|}{ (a) Season } \\
\hline Summer & 452.6 & 668.7 & 893.7 & 197.1 & 29.5 \\
\hline Autumn & 244.3 & 350.1 & 524.5 & 122.2 & 34.9 \\
\hline Winter & 104.5 & 224.5 & 346.7 & 98.9 & 44.1 \\
\hline Spring & 3.5 & 549.6 & 813.3 & 377.1 & 68.6 \\
\hline \multicolumn{6}{|c|}{ Runoff (mm) } \\
\hline Summer & 439.6 & 549.1 & 757.2 & 144.1 & 26.2 \\
\hline Autumn & 275.1 & 478.9 & 730.3 & 198.1 & 41.4 \\
\hline Winter & 199.3 & 276.5 & 367.7 & 69.2 & 25.0 \\
\hline Spring & 95.7 & 299.2 & 519.9 & 177.0 & 59.1 \\
\hline \multicolumn{6}{|c|}{ Runoff coefficient ( - ) } \\
\hline Summer & 0.58 & 0.85 & 1.03 & 0.20 & 23.15 \\
\hline Autumn & 0.82 & 1.39 & 1.80 & 0.42 & 29.91 \\
\hline Winter & 0.91 & 1.43 & 2.59 & 0.78 & 54.13 \\
\hline Spring & 0.42 & 7.21 & 27.34 & 13.43 & 186.31 \\
\hline \multicolumn{6}{|c|}{ (b) Month } \\
\hline \multicolumn{6}{|c|}{ Rainfall (mm) } \\
\hline January & 158.3 & 290.1 & 487.5 & 139.6 & 48.1 \\
\hline February & 148.0 & 175.7 & 219.5 & 31.5 & 17.9 \\
\hline March & 48.5 & 203.0 & 345.3 & 122.5 & 60.4 \\
\hline April & 135.3 & 194.7 & 327.0 & 89.9 & 46.2 \\
\hline May & 61.0 & 108.1 & 140.2 & 37.8 & 34.9 \\
\hline June & 8.1 & 47.4 & 63.5 & 26.3 & 55.5 \\
\hline July & 19.0 & 84.0 & 132.1 & 55.3 & 65.8 \\
\hline August & 12.3 & 36.4 & 82.0 & 32.5 & 89.3 \\
\hline September & 3.5 & 104.0 & 205.3 & 85.6 & 82.3 \\
\hline October & 119.5 & 158.3 & 212.2 & 39.8 & 25.1 \\
\hline November & 217.2 & 261.5 & 286.3 & 30.8 & 11.8 \\
\hline December & 172.9 & 266.8 & 382.2 & 102.6 & 38.4 \\
\hline \multicolumn{6}{|c|}{ Runoff (mm) } \\
\hline January & 96.9 & 171.9 & 241.3 & 59.2 & 34.4 \\
\hline February & 127.7 & 195.0 & 302.6 & 75.5 & 38.7 \\
\hline March & 132.2 & 182.2 & 215.0 & 39.7 & 21.8 \\
\hline April & 112.0 & 213.2 & 367.4 & 111.3 & 52.2 \\
\hline May & 100.2 & 156.5 & 211.6 & 52.8 & 33.7 \\
\hline June & 62.9 & 109.3 & 151.3 & 38.1 & 34.9 \\
\hline July & 70.7 & 99.8 & 150.7 & 35.5 & 35.6 \\
\hline August & 63.8 & 88.2 & 102.2 & 16.8 & 19.0 \\
\hline September & 64.8 & 88.6 & 114.8 & 21.6 & 24.3 \\
\hline October & 77.5 & 97.3 & 128.9 & 24.4 & 25.1 \\
\hline November & 89.9 & 117.0 & 162.4 & 31.5 & 26.9 \\
\hline December & 79.1 & 151.8 & 253.2 & 73.8 & 48.6 \\
\hline \multicolumn{6}{|c|}{ Runoff coefficient (mm) } \\
\hline January & 0.38 & 0.67 & 1.13 & 0.33 & 49.9 \\
\hline February & 0.81 & 1.12 & 1.71 & 0.42 & 37.5 \\
\hline March & 0.62 & 1.29 & 2.73 & 0.97 & 74.7 \\
\hline April & 0.83 & 1.07 & 1.24 & 0.18 & 16.3 \\
\hline May & 0.73 & 1.67 & 3.11 & 1.02 & 61.0 \\
\hline June & 0.99 & 4.41 & 11.94 & 5.06 & 114.7 \\
\hline July & 0.54 & 1.92 & 4.29 & 1.65 & 85.8 \\
\hline August & 1.14 & 4.07 & 7.46 & 2.82 & 69.4 \\
\hline September & 0.56 & 7.34 & 27.34 & 13.34 & 181.7 \\
\hline October & 0.49 & 0.62 & 0.80 & 0.13 & 21.2 \\
\hline November & 0.34 & 0.45 & 0.59 & 0.12 & 25.8 \\
\hline December & 0.39 & 0.58 & 0.78 & 0.20 & 34.6 \\
\hline
\end{tabular}

capability of the watershed was considerably lower $(0.85 \pm 0.20)$ (Table 3a).

It must be highlighted that the extreme value of the runoff coefficient calculated in spring $(7.21 \pm 13.43)$ throughout the observation period was affected by the considerably low precipitation measured in hydrological year 2007-2008, to which no similarly low runoff corresponded. However, by removing this outlier from the analysis (and by thus considering only 3 of the 4 hydrological years), a runoff coefficient of 0.49 was estimated in spring; this value showed that the share of precipitation turning into surface runoff was the lowest during this season compared to the other periods (Table $3 a$ ). 
On the monthly scale, the wettest month was January (290.1 \pm $139.6 \mathrm{~mm}$ of measured rainfall), while the driest was August (only $36.4 \pm 32.5 \mathrm{~mm}$ ). Surface runoff was at its highest in April (213 \pm $111 \mathrm{~mm}$ on average), with the lowest in August and September (about $88 \mathrm{~mm}$ ). The hydrological response of the watershed was maximum in September (runoff coefficient of $7.34 \pm 13.34$ ), while summer months (October to January) saw that $45 \%$ to $67 \%$ of precipitation turned into runoff. In the driest months (June, August and September), measured runoff was much higher than precipitation (Table 3b).

\subsection{Hydrological modelling of the watershed}

\subsubsection{Evaluating model performance}

Table 4 reports the statistics and other quantitative indexes used to evaluate the runoff prediction capability on the different time scales by default and the calibrated AnnAGNPS model in the Cunha watershed. By input default CN (63) for forest areas, the model's tendency to noticeably underestimate surface runoff, as shown by the CRM coefficient (0.75), was found. The model provided inaccurate runoff predictions on the aggregated scales (seasonal and monthly) (Figs. 4, 5 and 6), as confirmed by the negative or very low values of $\mathrm{E}(<0.13)$, and the discrepancies $(>70-80 \%)$ between the observed and predicted mean values of runoff. However, the correlations between the observed and predicted values were always high $\left(r^{2}>0.58\right.$ with a maximum of 0.84 on the seasonal scale). On the daily scale runoff was apparently predicted by AnnAGNPS with reliability but, in this case, the obtained $\mathrm{E}$ value (equalled 0.67 ) was somewhat misleading because the deviations between the daily observed and predicted values compensated (and the same was found for the erosive events) (Fig. 7a and b). Furthermore, the error between the observed and predicted means was considerable (about 80-90\%; Table 4).

This model's unsatisfactory performance forced the modeller to calibrate AnnAGNPS by increasing the initial CN of forest areas from 63 to 72 , and by thus attempting to reduce modelling errors. After CN calibration, AnnAGNPS' runoff underestimation tendency noticeably reduced (as shown by the reduction of CRM from 0.77 to a value close to zero), and the under-prediction seen for the default model practically disappeared. The input of the higher $\mathrm{CN}$ value generally gave runoff predictions that came closer to the corresponding observations on all the investigated time scales (Figs. 4, 5 and). The mean predicted runoff values came very close to the observed means, as detected in particular on the aggregated scales (seasonal and monthly), where differences were lower than $5 \%$. On the daily scale, the predicted mean runoff was much different from the corresponding observation (>60\%) (Fig. 7a and $\mathrm{b}$ ). The efficiency E index was satisfactory on all the investigated scales, even though it lowered from the annual to the daily scale (which usually happens). In general, prediction accuracy was more satisfactory for the runoff events with a higher magnitude. The mean error noticeably reduced (except on the daily scale) after $\mathrm{CN}$ calibration. However, the degree of correlation between observations and the runoff predictions lowered compared to the simulations performed by the default model ( $\mathrm{r}^{2}$ within the range from 0.58 , monthly scale, to 0.80 , seasonal scale) (Table 4$)$.

In spite of the calibration process, the worst model's performance was detected on the smaller temporal scales (Fig. 7a). The evaluation indexes $\left(r^{2}\right.$ and $E$ ) showed the lowest values which, however, could be

Table 4

Statistics and model evaluation criteria for the surface runoff observations and predictions by the AnnAGNPS model at the Cunha watershed outlet (Brazil).

\begin{tabular}{|c|c|c|c|c|c|c|c|c|c|}
\hline Time scale & Surface runoff & Initial CN (forest) & Mean $(\mathrm{mm})$ & Std. Dev. (mm) & $\operatorname{Min}(\mathrm{mm})$ & $\operatorname{Max}(\mathrm{mm})$ & $r^{2}$ & E & CRM \\
\hline \multicolumn{10}{|l|}{ Calibration (2005 and 2007) } \\
\hline \multirow{3}{*}{ Seasonal } & Observed & - & 113.78 & 125.22 & 5.87 & 337.16 & - & - & - \\
\hline & Predicted & Default & 28.35 & 33.48 & 1.37 & 106.70 & 0.84 & -0.09 & 0.75 \\
\hline & & Calibrated & 116.80 & 81.68 & 17.66 & 253.43 & 0.80 & 0.74 & -0.03 \\
\hline \multirow[t]{3}{*}{ Monthly } & Observed & - & 40.00 & 60.60 & 0.00 & 230.54 & - & - & - \\
\hline & Predicted & Default & 10.09 & 18.13 & 0.00 & 79.55 & 0.62 & 0.13 & 0.75 \\
\hline & & Calibrated & 38.71 & 42.7 & 0.00 & 160.33 & 0.58 & 0.57 & 0.03 \\
\hline \multirow[t]{3}{*}{ Daily } & Observed & - & 3.09 & 7.10 & 0.01 & 109.24 & - & - & - \\
\hline & Predicted & Default & 0.33 & 2.76 & 0.00 & 58.56 & 0.79 & 0.67 & 0.75 \\
\hline & & Calibrated & 1.27 & 6.04 & 0.00 & 98.76 & 0.65 & 0.54 & 0.03 \\
\hline \multirow[t]{3}{*}{ After erosive events (rainfall depth over $13 \mathrm{~mm}$ ) } & Observed & - & 6.83 & 12.93 & 0.10 & 109.24 & - & - & - \\
\hline & Predicted & Default & 2.28 & 6.96 & 0.00 & 58.56 & 0.81 & 0.66 & 0.56 \\
\hline & & Calibrated & 7.77 & 12.00 & 0.00 & 98.76 & 0.77 & 0.71 & -0.49 \\
\hline \multicolumn{10}{|l|}{ Validation (2006 and 2008) } \\
\hline \multirow[t]{2}{*}{ Seasonal } & Observed & - & 56.20 & 57.66 & 1.17 & 160.86 & - & - & - \\
\hline & Predicted & Calibrated & 48.71 & 48.32 & 6.25 & 158.67 & 0.55 & 0.52 & 0.13 \\
\hline \multirow[t]{2}{*}{ Monthly } & Observed & - & 18.68 & 23.01 & 0.00 & 80.19 & - & - & - \\
\hline & Predicted & Calibrated & 18.84 & 19.35 & 0.00 & 72.76 & 0.60 & 0.58 & 0.13 \\
\hline \multirow[t]{2}{*}{ Daily } & Observed & - & 1.81 & 2.39 & 0.00 & 15.61 & - & - & - \\
\hline & Predicted & Calibrated & 0.52 & 1.98 & 0.00 & 17.69 & 0.58 & 0.59 & 0.15 \\
\hline \multirow[t]{2}{*}{ After erosive events (rainfall depth over $13 \mathrm{~mm}$ ) } & Observed & - & 3.72 & 3.64 & 0.01 & 15.61 & - & - & - \\
\hline & Predicted & Calibrated & 3.74 & 4.05 & 0.01 & 17.69 & 0.56 & 0.42 & -0.45 \\
\hline \multicolumn{10}{|l|}{ Whole monitored period (2005-2008) } \\
\hline \multirow[t]{3}{*}{ Annual } & Observed & - & 352.06 & 332.54 & 115.26 & 884.71 & - & - & - \\
\hline & Predicted & Default & 82.45 & 83.11 & 32.08 & 206.15 & 0.97 & -0.45 & 0.77 \\
\hline & & Calibrated & 363.06 & 217.21 & 227.54 & 685.94 & 0.96 & 0.85 & -0.03 \\
\hline \multirow[t]{3}{*}{ Seasonal } & Observed & - & 88.01 & 108.90 & 1.17 & 337.16 & - & - & - \\
\hline & Predicted & Default & 20.61 & 28.24 & 0.00 & 106.7 & 0.80 & -0.01 & 0.77 \\
\hline & & Calibrated & 90.77 & 74.54 & 6.32 & 253.43 & 0.77 & 0.73 & -0.03 \\
\hline \multirow[t]{3}{*}{ Monthly } & Observed & - & 29.34 & 46.61 & 0.00 & 230.54 & - & - & - \\
\hline & Predicted & Default & 6.87 & 13.91 & 0.00 & 79.55 & 0.58 & 0.13 & 0.77 \\
\hline & & Calibrated & 30.26 & 36.91 & 0.00 & 160.33 & 0.51 & 0.51 & -0.03 \\
\hline \multirow[t]{3}{*}{ Daily } & Observed & - & 2.52 & 5.56 & 0.00 & 109.24 & - & - & - \\
\hline & Predicted & Default & 0.23 & 2.09 & 0.00 & 58.56 & 0.75 & 0.67 & 0.77 \\
\hline & & Calibrated & 0.99 & 4.88 & 0.00 & 98.76 & 0.62 & 0.44 & -0.03 \\
\hline \multirow[t]{3}{*}{ After erosive events (rainfall depth over $13 \mathrm{~mm}$ ) } & Observed & - & 5.41 & 9.94 & 0.01 & 109.24 & - & - & - \\
\hline & Predicted & Default & 1.62 & 5.39 & 0 & 58.56 & 0.78 & 0.59 & 0.59 \\
\hline & & Calibrated & 4.11 & 8.80 & 0 & 82.81 & 0.69 & 0.69 & -0.04 \\
\hline
\end{tabular}




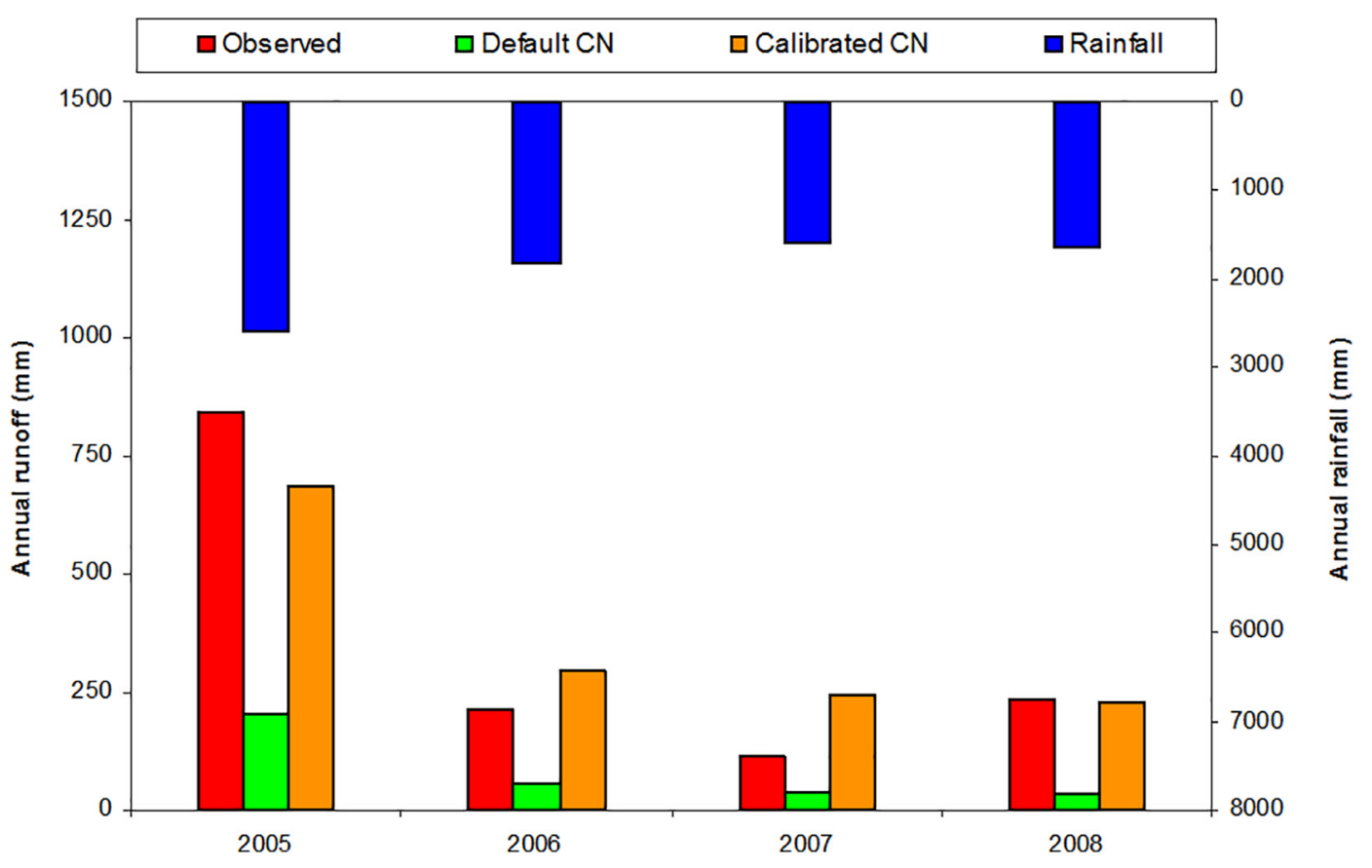

Fig. 4. - Annual runoff volumes observed at the outlet and simulated by the AnnAGNPS model (run with the default and calibrated initial CNs) in the Cunha watershed (Brazil).

considered satisfactory, and the observed and predicted means assumed the biggest difference (60\%). A further evaluation was made for the AnnAGNPS predictions of the runoff volumes subsequently to erosive rainfalls (i.e., precipitation with a depth over $13 \mathrm{~mm}$ ) to evaluate whether the analysed model could be used as prediction tool to control erosion on the watershed scale. After $\mathrm{CN}$ calibration, and as for the other time scales, the model's prediction capability was satisfactory (Fig. 7b) as the observed and predicted mean and maximum values differed by about $20 \%$, and model efficiency $(E=0.66)$ was above the suggested acceptance limit (0.35). Model simulations were more accurate for the highest runoff compared to non-extreme events (Table 4).

The benefits of the calibration process were evidenced by a subsequent evaluation of the calibrated model during the validation period. A reduced degree of correlation between observations and runoff predictions $\left(r^{2}<0.60\right)$ and the model's slight under-estimation behaviour (see CRM > 0) compared to the calibration period, were detected (Table 4). However, AnnAGNPS performed quite well on all the time scales. The best model performances were found on the aggregated scales (seasonal and monthly). More specifically, model efficiency was satisfactory $(E>0.58)$ on the seasonal, monthly and daily scales, and decreased to 0.42 on the event scale, be it over the acceptance limit. The differences between the mean observed and predicted runoff volumes were lower than $10 \%$ on the seasonal and monthly scales, but increased to about $70 \%$ on the daily scale (Table 4 ).

Overall, the evaluation over the entire period (2005-2008) showed that, provided that the model was calibrated: (i) AnnAGNPS tended to overestimate the observed runoff volumes; (ii) the model was able to make more accurate predictions of surface runoff on the aggregated time scales (annual, seasonal and monthly), as shown by $\mathrm{E}>0.51$, and the differences between the observed/predicted means were lower

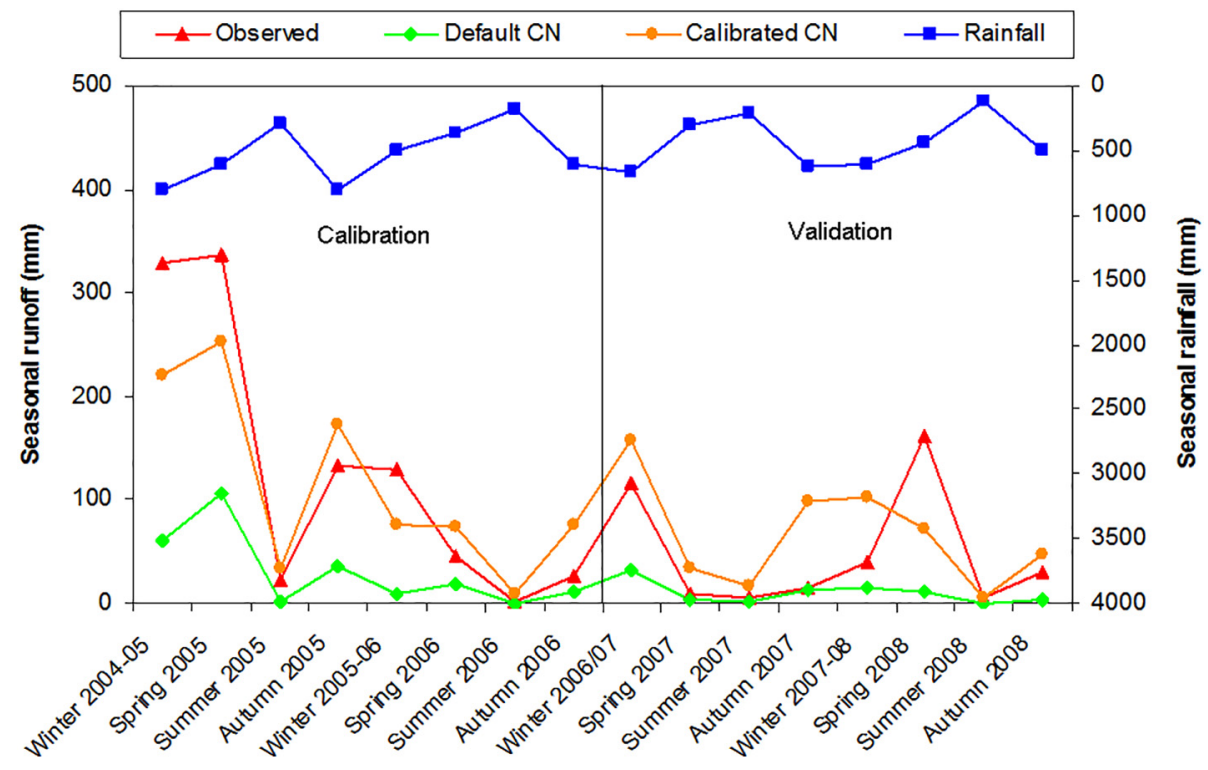

Fig. 5. - Seasonal runoff volumes observed at the outlet and predicted by the AnnAGNPS model (run with the default and calibrated initial CNs) in the Cunha watershed (Brazil). 


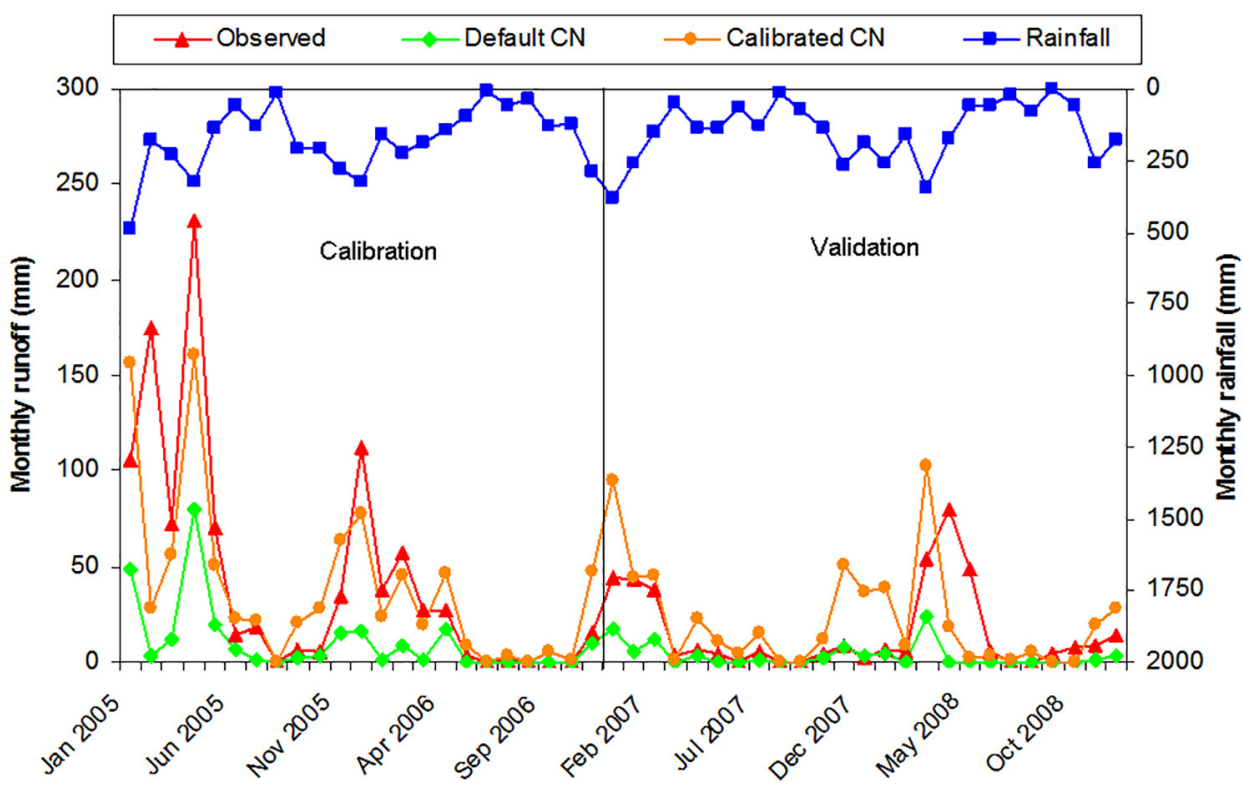

Fig. 6. - Monthly runoff volumes observed at the outlet and predicted by the AnnAGNPS model (run with the default and calibrated initial CNs) in the Cunha watershed (Brazil).

than $10 \%$; (iii) its runoff prediction became worse on the daily scale when $\mathrm{E}$ decreases to 0.44 , and the differences between the mean runoff volumes increased to $60 \%$; (iv) on the event scale, the coefficient of efficiency was good $(E=0.69)$, but the differences between the mean and maximum values of the observed and predicted runoff volumes were not negligible (over 25\%) (Table 4).

\subsubsection{Analysis of the hydrological cycle}

For the most accurate predictions of rainfall events with erosive effects provided by the AnnAGNPS model, the hydrological balance was performed and water losses were quantified. On average, runoff and infiltration represented $14.8 \%$ (with a minimum of $2.8 \%$ and a maximum of 24.3 ) and $61.9 \%$ (minimum $54.8 \%$, maximum 69.5\%), respectively, of total rainfall, while interception and evapo-transpiration accounted for $16.4 \%$ (range of variability $15.7-17.6 \%$ ) and $7.0 \%$ (0.0-24.8\%), respectively, of the rainfall fallen during the event (Fig. 8). Very high correlations $\left(\mathrm{r}^{2}>0.94, p<0.05\right)$ were detected between precipitation on the one hand and surface runoff and infiltration on the other hand. The coefficient of determination between rainfall and potential evapotranspiration was lower $(0.42)$, but significant $(p<0.05)$ (data not shown), presumably due to the noticeable influence of temperature (beside precipitation) on the ET values.

\section{Discussion}

\subsection{Hydrological characterisation of the watershed}

Water balance is the accounted entry and exit of water in the watershed, precipitation is the main source of water that enters the system, and hidden the precipitation from fog and dew at night contributes a small percentage (Cecílio et al., 2013). Cerdá et al. (2017) emphasises that flow is the result of the interaction linking runoff, vegetation and the basin physiographic process and, along with evapo-transpiration from plants, it consists of the main causes of water output from the system.

The hydrological monitoring of the experimental watershed by the water balance done on different time scales showed limited variations of precipitation over the area from 1 year to another during the observation period $(C V=13.5 \%)$ and a slightly higher variability of surface runoff $(\mathrm{CV}=24.2 \%)$. Based on these data, annual runoff coefficients within the $0.71-0.96$ range, with a mean value of 0.86 and a variability of about $11 \%$, were calculated (Table 2 , 3a and b).
On lower time scales, the analysis showed, as response to long low rainfall periods that occurred from May to September, that river flows decreased during the dry season, but the water availability in the watershed was maintained, which could be attributed mainly to groundwater reserves. The seasonal hydrograph was delayed compared to the seasonal rainfall distribution: maximum and minimum stream flows were usually observed in February to April and July to September, respectively; maximum and minimum precipitations were recorded instead in November to January and June to August, respectively. The monthly observations made during the rainy (October to March) and dry (April to September) periods showed large quantitative differences in rainfall between seasons ( $C V=56 \%$ ) and months $(C V=66 \%)$, but flow during the same period demonstrated more stability and lower fluctuations (seasonal CV $=43 \%$, monthly $C V=46 \%$ ) (Table 3a and b), which may be due to a time lag between surface runoff and water infiltrating on the subsurface layer and flowed as a baseflow throughout the year (also observed by Fujieda et al., 1997). This time lag between precipitation and the watershed's hydrological response was due to the water storage capacity of soil. In other words, given the different filtration velocities of these water flows (with differences of some orders of magnitude), the share of precipitation, not lost through interception and evapo-transpiration and not turned into surface runoff, infiltrated into soil during the wetter period (when precipitation was higher) and got the hydrographic network (as surface flow) was obtained after many days or weeks during the drier season. This delaying process broadened the base flow and reduced the maximum flow of watercourses (Cecílio et al. 2013), which made surface flows quite stable throughout the year. This hydrological response of the watershed covered by Mata Atlantica has been marked as a "counter clock-wise hysteresis loop effect” by Fujieda et al. (1997). Over a 10-year monitoring period, in the same watershed these authors observed the maximum value of the monthly stream flow between January and March, and the minimum one between May and August. This monthly stream flow was much higher compared to the rainfall during this period. Moreover, infiltration reduced erosion and increased the recharge of aquifers because some of the water replenished the water table.

The other losses observed in the experimental watershed were interception and evapo-transpiration, where forest cover plays a basic role. As soil evaporation is largely negligible in the forest, ET is practically represented by plant transpiration. As a matter of fact, use of water by plants or transpiration (water movement through the soilplant-atmosphere) is the most important transfer of water from soil to 

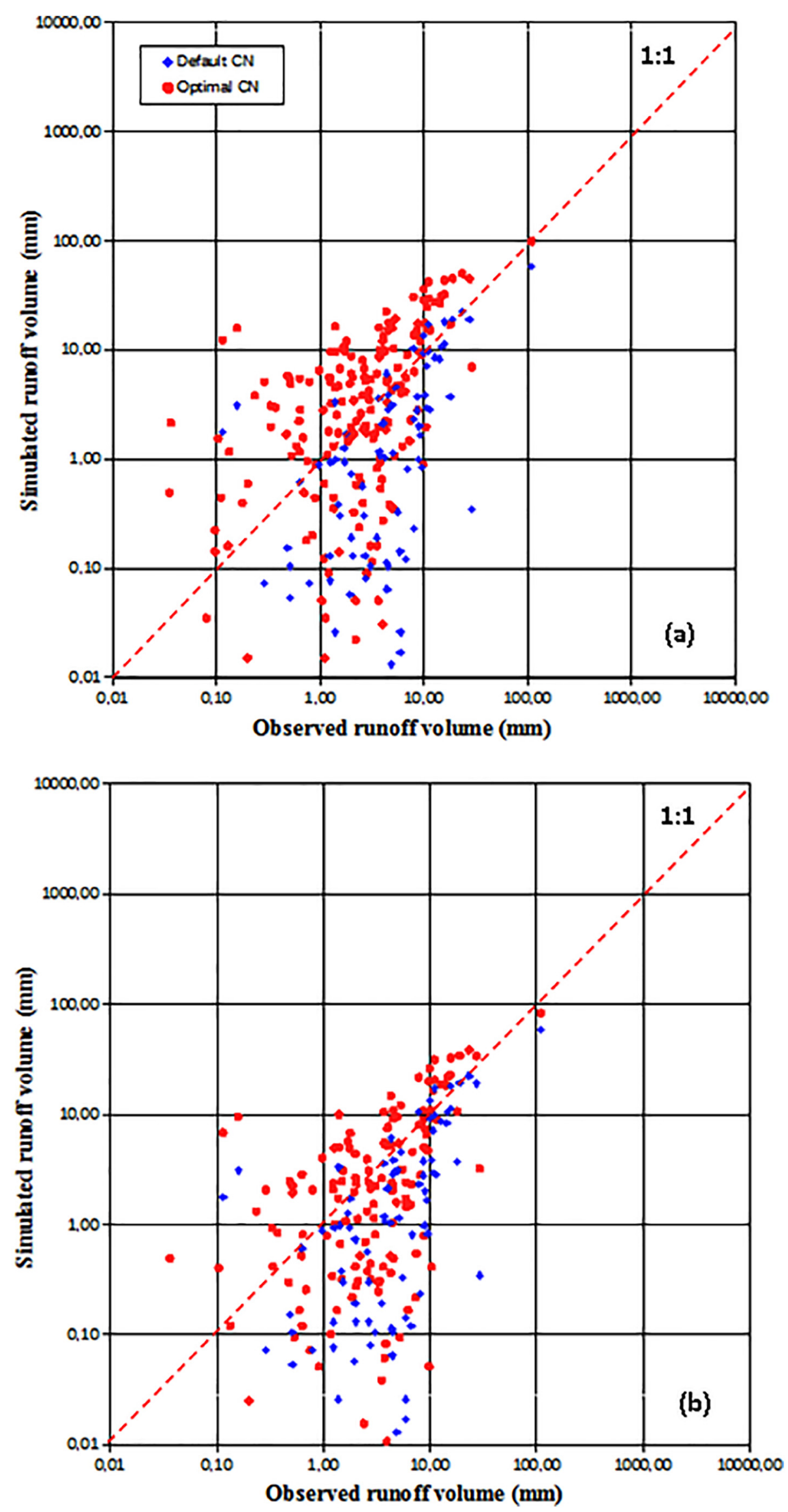

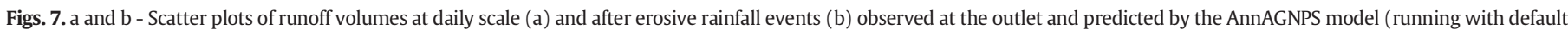
and calibrated initial CNs) in the Cunha watershed (Brazil). 


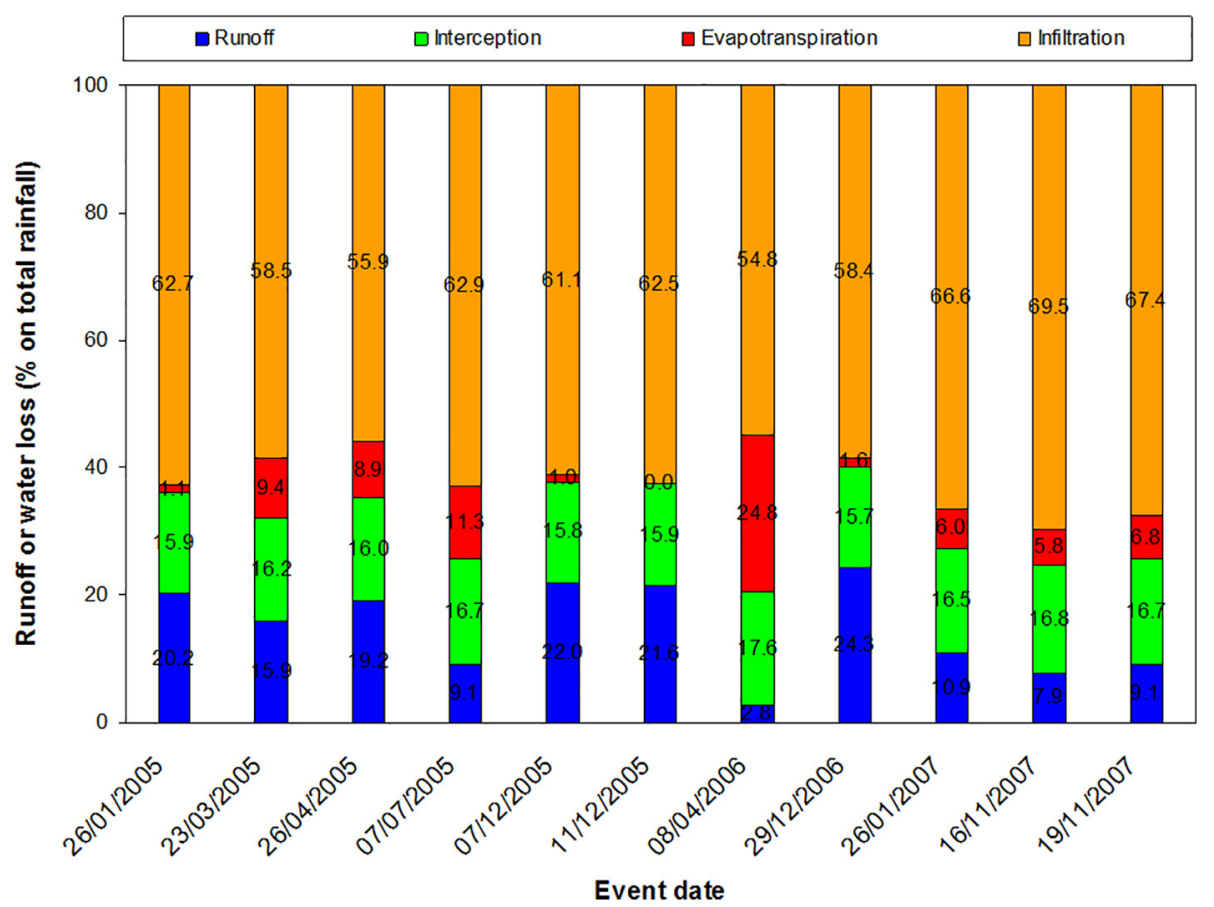

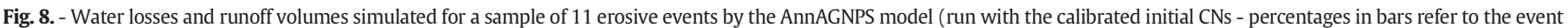
rainfall) in the Cunha watershed (Brazil).

the atmosphere mechanism, when soil is covered by forest vegetation (Zimmerman et al., 2000). The mean monthly potential evapotranspiration during the observation period came very close or exceeded the mean monthly rainfall only in August. This means that the Cunha watershed must have an adequate water supply to maintain such potential evapo-transpiration throughout the year.

On the annual time scales, in the water balance the share of rainfall intercepted by canopy cover and returned directly to the atmosphere amounted to about $20 \%$ on average (complying findings to those of other authors, who have reported crown interception in Brazilian forests to lie between $16 \%$ and $22.0 \%$, Coelho Netto et al., 1986; Leopoldo and Conte, 1985; Franken et al., 1982a, 1982b), while the water volume lost through evapo-transpiration has been estimated to be $45 \%$ of total precipitation (Table 2). In the same watershed, during the 1983-1992 observation period, Fujieda et al. (1997) reported I and ET percentages of $30 \%$ and $15 \%$ of total annual precipitation, respectively; Leopoldo et al. (1995) found ET and I equalled $67.6 \%$ and $11.3 \%$, respectively, in a small watershed in central Brazil. The water balance of the watershed under study confirmed the positive effect of forest because it provided greater water infiltration and storage in soil, replenished groundwater and improved flow regularity. Consequently, the watershed was under humid conditions throughout the year, even during the dry season. Vegetation would, therefore, be related to soil permeability, determined in the regular flow of rivers. It must also be stressed that, despite the high rainfall and slope rates in Serra do Mar (to which the Cunha watershed belongs), forest protection greatly contributes to erosion control (Schumacher and Hoppe, 1998) but, at the same time, supplies the aquifer by supporting a suitable infiltration rate, and assuring water availability in spring (Rodrigues, 2014). On the whole, the watershed covered by forest confers hydrological processes stability.

\subsection{Hydrological modelling of the watershed}

The inability of the AnnAGNPS, implemented by the default initial CNs (equal to 63) as input, to accurately simulate the surface runoff volume on all the investigated time scales (shown by its marked underestimation tendency), indicates the need for model calibration to make simulations come close to observations. The need for $\mathrm{CN}$ adjustments to increase the model's prediction capability has also been claimed by other authors (e.g. Sarangi et al., 2007; Shrestha et al., 2006; Shamshad et al., 2008), who have applied the AnnAGNPS model to the same climate conditions. This need is basically due to AnnAGNPS' internal nature which, unlike most watershed models, does not use conservation-based continuity equations to maintain water balance (Borah and Bera, 2004), but calculates daily and subdaily water budgets by the SCS TR-55 method (SCS, 1986). To determine the amount of runoff, the model changes daily $\mathrm{CN}$ using antecedent moisture conditions based on soil hydrological constants. This produces unrealistic CN values during simulations and noticeable under- or over-estimations of runoff, as previously indicated by some authors (e.g. Zema et al., 2016; Polyakov et al., 2007). This behaviour can be controlled to a point by proper calibration processes by tuning the initial CNs for the largest homogenous areas in watersheds.

When the initial $\mathrm{CN}$ of forest increased to 72 , the model provided more reliable runoff estimations, as shown by the closeness between the mean values of the predicted and simulated runoff volumes (difference $<3 \%$ ) and the satisfactory values of the coefficients of efficiency on the aggregated scales (see the model's annual, seasonal and monthly performances during the 2005-2008 aggregate period) (Table 4). By increasing the initial $\mathrm{CN}$, the model's tendency to underestimate runoff volumes reduced, particularly for lower magnitude events, which also explains the need for model calibration. In general, the accurate runoff predictions provided by AnnAGNPS could also be due to both soil texture/land use homogeneity, which reduces the error source in model parameterisation, and the small experimental watershed size, since the smaller the watershed, the more satisfactory the model prediction (Parajuli et al., 2009; Taguas et al., 2009; Chahor et al., 2014).

This accuracy in simulating monthly runoff shown by AnnAGNPS in the experimental watershed was more appreciable compared with the simulations of Fujieda et al. (1997), who used simple linear regression equations between monthly rainfall and runoff volumes. As a matter of fact, by reproducing the monthly stormflows of the 2005-2008 observation period by these equations, a mean value of $12.41 \mathrm{~mm} / \mathrm{month}$ was obtained, as opposed to the $30.26 \mathrm{~mm} / \mathrm{month}$ simulated by AnnAGNPS, which came very close to the observed value 
of $29.34 \mathrm{~mm} / \mathrm{month}$ (Table 4). Polyakov et al. (2007) have also reported satisfactory model performance on the annual and monthly scales in the runoff predictions under the same climate conditions (Hawaii, USA); better results ( $r^{2}$ up to 0.92 and $E$ up to 0.85 ) in the modelling surface runoff by AnnAGNPS in a Malaysian watershed have been detected by Shamshad et al. (2008) who, however, estimated peak flow instead of runoff volume. Hua et al. (2012) have reported exceptionally high coefficients of efficiency ( 0.94 in the calibration phase and 0.93 for validation) in the monthly simulations of runoff in a tropical watershed of China (tributary of Yangtze river). By calibrating AnnAGNPS in microcatchments in south Spain, but in different environmental contexts, Taguas et al. (2009) have also reported better results on a monthly scale than on an event scale as a result of the model's sensitivity to appropriately select the $\mathrm{CN}$ values for individual events.

The runoff prediction capability of AnnAGNPS on lower time scales (daily and event scales) in the Cunha watershed was less accurate and not very satisfactory in some cases (as shown by the difference between daily observations and predictions, which were up to $60 \%$ ). This has also been noticed by Polyakov et al. (2007). In a watershed under semi-arid conditions (Navarre, Spain), Chahor et al. (2014) have shown that AnnAGNPS satisfactorily simulated the surface runoff on monthly, seasonal and annual scales in both calibration and validation processes. As regards other modelling experiences completed under tropical conditions, Shrestha et al. (2006) have report runoff under-estimations by AnnAGNPS that were no higher than 15-22\% for AnnAGNPS implementation in a subtropical watershed of Nepal; Sarangi et al. (2007) have observed that AnnAGNPS usually requires increased CNs for accurate runoff predictions, particularly due to the model's soil moisture budgeting module, which partitions relatively high volumes of precipitation to evapo-transpiration losses on account of the high year-round temperatures of their conditions (experimental watershed in Santa Lucia, British West Indies), which are typical of tropical zones. The same authors found difficulties in accurately reproducing the rainfall-runoff transformation in forest watershed, and this hydrological process was influenced by canopy interception, evapotranspiration and basin storage of water at variable degrees (Sarangi et al., 2007). The better runoff prediction capability shown by the AnnAGNPS for longer time scale simulations could be due to the balance of the underestimation/overestimation errors that aggregation of more data generally determines.

On the whole, provided that the initial $\mathrm{CN}$ is calibrated, the runoff prediction accuracy shown by the analysed model is considered satisfactory for aggregated scales, and good on the annual scale. Thus the model could be useful for evaluating water production in the experimental watershed. Conversely, runoff simulations on the daily and event scales are less reliable and these estimations must be processed with caution. These results, which indicate that the SCS Curve Number method is suitable for runoff predictions under experimental conditions, led us to think that, under experimental conditions, the AnnAGNPS model is more suitable for longer time scales predictions. In other words, the model can be reliably used to predict the effects of land use and/or climate changes on the hydrological response of such a small tropical forest watershed on long time scales (years, seasons or months). Conversely, the simulation of the effects of soil erosion and/or contaminant runoff processes, which are related more to shorter time scales, on basin morphology and/or water quality require improving AnnAGNPS' prediction capability on daily and event scales.

The incidence of the evapo-transpiration and other water losses due to the role played by, such as the interception, on total rainfall was quantified by simulating the hydrological cycle by AnnAGNPS for a sample of selected rainfall-runoff events. This evaluation also confirmed on the event scale the high incidence of infiltration on the water input into the studied watershed since the model showed that ground storage in the watershed represented $>60 \%$ of total rainfall, while the surface flow covered a share of $15 \%$ of precipitation. These values agree with the findings of Fujieda et al. (1997), who reported on the annual scale shares of surface runoff and water storage that equalled $11 \%$ and $59 \%$, respectively, of total precipitation. The large amounts of water infiltrated during the analysed events confirmed that seepage recharging effects were due to infiltration losses, which have already been noticed by the hydrological analysis performed in the experimental watershed by the above cited authors. Conversely, the effect of forest vegetation on water retention during precipitation, evapo-transpiration and interception, were only $7.0 \%$ and $16.4 \%$, respectively, of the total input rainfall during the event, A portion of water was retained in pore spaces, a part was absorbed by plants or evaporated from the soil surface, and the other fed the aquifers that were the saturated horizon of the soil profile (as also noted by Loureiro, 1983), while canopy interception played a minor role in this hydrological balance. Therefore during the most erosive storm events, the mitigation effects played by forest vegetation through evapo-transpiration and interception (only $20-25 \%$ of the total water input on average) was much weaker compared to the rates detected by the above-reported time-aggregated analysis.

\section{Conclusions}

Given the ecological importance of the Atlantic forests of Brazil and the complexity of their hydrological cycle, this study evaluated the suitability of the AnnAGNPS to model the surface runoff and the water balance of a small forested watershed of Brazil under tropical conditions on different time scales. The prior hydrological characterisation of the experimental watershed performed on the annual scale showed that the water availability throughout the 4 -year observation period could be attributed mainly to groundwater reserves, fed by the high water infiltration through soil. In addition, the evapo-transpiration of forest trees plays an important role in the hydrological balance, and this loss represents some $45 \%$ of total precipitation and facilitates water infiltration.

As regards the simulation of the hydrological response of a small watershed, the poor performance in simulating runoff shown by the model, which was run with default $\mathrm{CNs}$, required the initial $\mathrm{CN}$ of forest to be modified. After calibration, the runoff prediction capability of AnnAGNPS became satisfactory on annual, seasonal and monthly scales, as shown by the subsequent model validation. On lower time scales, the model's runoff predictions were less accurate, mostly on the daily and event scale.

The calibrated CN values, which increased AnnAGNPS' accuracy in predicting surface runoff in the experimental watershed, differed from the values reported by the technical manuals of both AnnAGNPS and the SCS-CN model. Therefore, the optimal CN values for tropical forests (equal 72 instead of 63) achieved herein on the watershed scale could be included in the database of the AnnAGNPS model by developers.

Modelling water losses by AnnAGNPS on the event scale showed that the effect of forest vegetation on water retention during a single precipitation was more limited than for longer periods (months, seasons and years), and accounted for evapo-transpiration and mainly interception for small total precipitation shares.

Overall, the study demonstrated that, besides the basic hydrologic role of vegetation in the water balance of tropical forests, the AnnAGNPS model was useful for evaluating the water cycle in the tropical forest watershed. The model's implementation, thanks to the satisfactory accuracy of its runoff predictions, could be an important tool for water resource and forest management in tropical forests. Particularly in Brazil, where reliable stream flow series in ungauged watersheds are needed to predict the effects of land use or climate change on runoff, sediment transport and water quality, the well-established use of this rainfallrunoff model could support the adoption of potential strategies for managing watersheds for territory planners and forest managers in view of the conservation of these delicate ecosystems. 


\section{References}

Aguiar, O.T., Pastore, J.A., Rocha, F.T., Baitello, J.B., 2001. Flora fanerogamic a stretch of Secondary Dense Forest in the Serra do Mar State Park - Core Cunha/Indaiá (SP). Journal of Forestry Institute-São Paulo 13 (1), 1-18.

AnnAGNPS, 2001. AnnAGNPS Version 2 user Documentation. USDA-ARS, Washington, DC Available at. www.ars.usda.gov (Last access 18 March 2017).

Arabi, M., Govindaraju, R.S., Hantush, M.M., 2006. Role of watershed subdivision on evaluation of long-term impact of best management practices on water quality. J. Am. Water Resour. Assoc. 42, 513-528.

Ataroff, V., Rada, F., 2000. Deforestation impact on water dynamics in a Venezuelan Andean cloud forest. Ambio 29, 440-444.

SOS Atlantic Forest and INPE, 2013. The National Institute for Space Research - Atlas of Forest Remnants of Atlantic Rainforest. Technical Report, São Paulo, Brazil.

Baginska, B., Milne-Home, W., Cornish, P.S., 2003. Modelling nutrient transport in Currency Creek, NSW with AnnAGNPS and PEST. Environ. Model. Softw. 18, 801-808.

Beskow, S., Mello, C.R., Norton, L.D., Da Silva, A.M., 2011. Performance of a distributed semi-conceptual hydrological model under tropical watershed conditions. Catena 86 (3), 160-171.

Bingner, R.L., Theurer, F.D., 2005. AnnAGNPS Technical Processes Documentation, Version 3.2. USDA-ARS National Sedimentation Laboratory, Oxford, MS.

Borah, D.K., Bera, M., 2004. Watershed-scale hydrologic and nonpoint-source pollution models: review of applications. Transactions of the ASAE 47 (3), 789-803.

Cecílio, R.A., Martinez, M.A., Pruski, F.F., Silva, D.D., 2013. Model to predict water infiltration and soil moisture profile. Revista Brasileira de Ciência do Solo 37 (2), 411-421.

Cerdá, A., Lucas-Borja, M.E., Úbeda, X., Martínez-Murillo, J.F., Keesstra, S., 2017. Pinus halepensis M. versus Quercus ilex subsp. Rotundifolia L. runoff and soil erosion at Pedon scale under natural rainfall in Eastern Spain three decades after a forest fire. For. Ecol. Manag. 400, 447-456.

Chahor, Y., Casali, J., Gimenez, R., Bingner, R.L., Campo, M.A., Goni, M., 2014. Evaluation of the AnnAGNPS model for predicting runoff and sediment yield in a small Mediterranean agricultural watershed in Navarre (Spain). Agric. Water Manag. 134, 24-37.

Chow, V.T., 1964. Handbook of Applied Hydrology. McGraw-Hill, New York, USA.

Chow, V.T., Maidment, D.R., Mays, L.W., 1988. Applied Hydrology. McGraw-Hill, New York, USA.

Cicco, V., Emmerich, W., Fujieda, M., 1987. Determinacao da curva-chave do vertedouro da bacia hidrografica experimental 'D' no parque estadual da Serra do Mar. Nucleo Cunha. 41. SP. Bol. Tec. IF, Sao Paulo, pp. 79-96 (in Portuguese with English abstract).

Coelho Netto, A.L., Sanche, M., Peixoto, M.N., 1986. Precipitacao e interceptacao florestal em ambiente tropical montanhoso, Rio de Janeiro. Rev. Bras. Eng. 4, 55-71 (in Portuguese with English abstract).

Das, S., Rudra, R.P., Goel, P.K., Gharabaghi, B., Gupta, N., 2006. Evaluation of AnnAGNPS in cold and temperate regions. Water Sci. Technol. 53, 263-270.

Douglas-Mankin, K.R., Srinivasan, R., Arnold, J., 2010. Soil and water assessment tool (SWAT) model: current developments and applications. Trans. ASABE 53, 1423-1431.

Franken, W., Leopoldo, P.R., Matsui, E., Ribeirom, N.G., 1982a. Estudo de interceptacao da agua de chuva em cobertua florestal amazonica do tipo terra firme. Acta Amazon. 12 327-331 (in Portuguese with English summary).

Franken, W., Leopoldo, P.R., Matsui, E., Ribeirom, N.G., 1982b. Interceptacao das precipitacoes em floresta amazonica de terra firme. Acta Amazon. 12, 15-22 (in Portuguese with English summary).

Fujieda, M., Kudoha, T., de Cicco, V., de Calvarcho, J.L., 1997. Hydrological processes at two subtropical forest catchments: the Serra do Mar, Sao Paulo, Brazil. J. Hydrol. 196, 26-46.

Galindo-Leal, C., Câmara, I.G., 2005. Status do hot spot Atlantic: a synthesis. In: GalindoLeal, C., Hall, I.G. (Eds.), Atlantic Forest Biodiversity, Threats and Prospects. Sao Paulo: Fundação SOS Mata Atlântica, Belo Horizonte, Brazil.

Geter, W.F., Theurer, F.D., 1998. AnnAGNPS-RUSLE sheet and rill erosion. 1st Federal Interagency Hydrologic Modeling Conference 1: 1-17 to 1-24. Interagency Advisory Committee on Water Data, Subcommittee on Hydrology, Washington, DC.

Hua, L., He, X., Yuan, Y., Nan, H., 2012. Assessment of runoff and sediment yields using the AnnAGNPS model in a three-gorge watershed of China. Int. J. Environ. Res. Public Health 9, 1887-1907.

Japan International Cooperation Agency (JICA), 1980. Report of Implementation Design Survey on the Japanese Technical Cooperation Project for the Forestry Research in Sao Paulo, Brazil. FDD-JR-80-59 (284 pp).

Kirpich, Z.P., 1940. Time of concentration of small agricultural watersheds. Civ. Eng. 10 (6), 362.

Klemes, V., 1986. Operational testing of hydrological simulation models. Hydrol. Sci. J. 31, $13-24$.

Kliment, Z., Kadlec, J., Langhammer, J., 2008. Evaluation of suspended load changes using AnnAGNPS and SWAT semi-empirical erosion models. Catena 73, 286-299.

Krause, P., Boyle, D.P., Base, F., 2005. Comparison of different efficiency criteria for hydrological model assessment. Adv. Geosci. 5, 89-97.

Legates, D.R., McCabe, G.J., 1999. Evaluating the use of "goodness of fit" measures in hydrologic and hydroclimatic model validation. Water Resour. Res. 35, 233-241.

Leopoldo, P.R., Conte, M.L., 1985. Reparticao da agua de chuva em cobertura vegetal com caracterısticas tıpicas de cerradao. Simposio Brasileiro de Hidrologia e Recursos Hidricos. Associacao Brasileira de Hidrologia e Recursos Hidricos, Anais, Sao Paulo, pp. 212-220.

Leopoldo, P.R., Franken, W.K., Nova, N.A.V., 1995. Real evapotranspiration and transpiration through a tropical rain forest in central Amazonia as estimated by the water balance method. For. Ecol. Manag. 73 (1-3), 185-195.

Licciardello, F., Zema, D., Zimbone, S., Bingner, R., 2007. Runoff and soil erosion evaluation by the AnnAGNPS model in a small Mediterranean watershed. Trans. ASABE 50, 1585-1593.
Liu, J., Zhang, L., Yuzhen, Z., Hong, H., Deng, H., 2008. Validation of an agricultural nonpoint source (AGNPS) pollution model for a catchment in the Jiulong river watershed, China. J. Environ. Sci. (China) 20, 599-606.

Liu, J., Wang, S., Li, D., 2014. The analysis of the impact of land-use changes on flood exposure of Wuhan in Yangtze river basin, China. Water Resour. Manag. 28, 2507-2522.

Loague, K., Green, R.E., 1991. Statistical and graphical methods for evaluating solute transport models: overview and application. J. Contam. Hydrol. 7, 51-73.

Loureiro, B.T., 1983. Groundwater irrigation: production with stability. Agriculture Report. 9(100), pp. 48-52.

Marmontel, C.V.F., Lucas-Borja, M.E., Rodrigues, V.A., Zema, D.A., 2018. Effects of land use and sampling distance on water quality in tropical headwater springs (Pimenta Creek, São Paulo State, Brazil). Sci. Total Environ. 622, 690-701.

de Mello, C.R., Norton, L.D., Campos Pinto, L., Beskow, S., Curi, N., 2016. Agricultural watershed modeling: a review for hydrology and soil erosion processes. Ciência e Agrotecnologia 40 (1), 7-25.

Moisello, U., 1999. Idrologia tecnica. La Goliardica Pavese, Pavia, Italy, p. 768 (in Italian).

Moriasi, D.N., Arnold, J.G., Van Liew, M.W., Bingner, R.L., Harmel, R.D., Veith, T.L., 2007. Model evaluation guidelines for systematic quantification of accuracy in watershed simulations. Trans. ASABE 50 (3), 885-900.

Nash, J.E., Sutcliffe, J.V., 1970. River flow forecasting through conceptual models: part I. A discussion of principles. J. Hydrol. 10, 282-290.

Neill, C., Deegan, L.A., Thomas, S.M., Cerri, C.C., 2001. Deforestation for pasture alters nitrogen and phosphorus in small Amazonian streams. Ecol. Appl. 11, 1817-1828.

Neill, C., Elsenbeer, H., Krusche, A.V., Lehmann, J., Markewitz, D., de O Figueiredo, R., 2006. Hydrological and biogeochemical processes in a changing Amazon: results from small watershed studies and the large-scale biosphere-atmosphere experiment. Hydrol. Process. 20 (12), 2467-2476.

Parajuli, P.B., Nelson, N.O., Frees, L.D., Mankin, K.R., 2009. Comparison of AnnAGNPS and SWAT model simulation results in USDA-CEAP agricultural watersheds in southcentral Kansas. Hydrol. Process. 23, 748-763.

Pease, L.M., Oduor, P., Padmanabhan, G., 2010. Estimating sediment, nitrogen, and phosphorous loads from the Pipestem Creek watershed, North Dakota, using AnnAGNPS. Comput. Geosci. 36, 282-291.

Polyakov, V., Fares, A., Kubo, D., Jacobi, J., Smith, C., 2007. Evaluation of a non-point source pollution model, AnnAGNPS, in a tropical watershed. Environ. Model. Softw. 22, 1617-1627.

Rawls, W.J., Gish, T.J., Brakensiek, D., L, 1991. Estimating soil water retention from soil physical properties and characteristics. Adv. Soil Sci. 16, 213-234.

Rodrigues, V.A., 2014. Evaluation of hydrological processes in watersheds. Thesis (Free Teaching) the State University Paulista. Faculty of Agricultural Sciences. Botucatu, Brazil.

Rodrigues, V., Estrany, J., Ranzini, M., de Cicco, V., Martín-Benito, J.M.T., Hedo, J., LucasBorja, M.E., 2017. Effects of land use and seasonality on stream water quality in a small tropical catchment: the headwater of Córrego Água Limpa, São Paulo (Brazil). Sci. Total Environ. 622-623, 1553-1561.

Sarangi, A., Cox, C.A., Madramootoo, C.A., 2007. Evaluation of the AnnAGNPS model for prediction of runoff and sediment yields in St Lucia watersheds. Biosyst. Eng. 97, 241-256.

Schumacher, M.V., Hoppe, J.M., 1998. The forest and water. AFUBRA, v.2 (Porto Alegre, Brazil).

SCS, 1986. Urban Hydrology for Small Watersheds. Technical Release 55. USDA-SCS, Washington, DC.

Shamshad, A., Leow, C.S., Ramlah, A., Wan Hussin, W.M.A., Mohd, S.A., 2008. Sanusi applications of AnnAGNPS model for soil loss estimation and nutrient loading for Malaysian conditions. Int. J. Appl. Earth Obs. Geoinf. 10, 239-252.

Shi, P., Ma, X., Hou, Y., Li, Q., Zhang, Z., Qu, S., Chen, C., Cai, T., Fang, X., 2013. Effects of landuse and climate change on hydrological processes in the upstream of Huai river, China. Water Resour. Manag. 27, 1263-1278.

Shrestha, S., Babel, M.S., Das Gupta, A., Kazama, F., 2006. Evaluation of annualized agricultural nonpoint source model for a watershed in the Siwalik hills of Nepal. Environ. Model. Softw. 21, 961-975.

Silvano, R.A.M., Udvardy, S., Ceroni, M., Farley, J., 2005. An ecological integrity assessment of a Brazilian Atlantic Forest watershed based on surveys of stream health and local farmers' perceptions: implications for management. Ecol. Econ. 53, 369-385.

Singh, V.P., Woolhiser, D.A., 2002. Mathematical modeling of watershed hydrology. J. Hydrol. Eng. 7, 270-292.

Srivastava, P., Hamlett, J.M., Robillard, P.D., Day, R.L., 2002. Watershed optimization of best management practices using AnnAGNPS and a genetic algorithm. Water Resour. Res. 38 (3).

Taguas, E.V., Ayuso, J.L., Pena, A., Yuan, Y., Perez, R., 2009. Evaluating and modelling the hydrological and erosive behaviour of an olive orchard microcatchment under notillage with bare soil in Spain. Earth Surf. Process. Landf. 34, 738-751.

USDA, 1972. National Engineering Handbook. Section 4: Hydrology.

Van Liew, M.W., Garbrecht, J., 2003. Hydrologic simulation of the Little Washita River experimental watershed using SWAT. J. Am. Water Resour. Assoc. 39, 413-426.

Verstraeten, G., Van Rompaey, A., Poesen, J., Van Oost, K., Govers, G., 2003. Evaluating the impact of watershed management scenarios on changes in sediment delivery to rivers? Hydrobiologia 494 (1-3), 153-158.

Viola, M.R., Mello, C.R., Beskow, S., Norton, L.D., 2014. Impacts of land-use changes on the hydrology of the Grande river basin headwaters, southeastern Brazil. Water Resour. Manag. 28 (13), 4537-4550.

Whitmore, T.C., 1990. An Introduction to Tropical Rain Forests. Clarendon Press, Oxford, UK.

Willmott, C.J., 1982. Some comments on the evaluation of model performance. Bull. Am. Meteorol. Soc. 63 (11), 1309-1313. 
Wohl, E., Barros, A., Brunsell, N., Chappell, N.A., Coe, M., Giambelluca, T., Goldsmith, S. Harmon, R., Hendrickx, J.M.H., Juvik, J., McDonnell, J., 2012. The hydrology of the humid tropics. Nat. Clim. Chang. 2 (9), 655.

Yuan, Y., Bingner, R.L., Rebich, R.A., 2001. Evaluation of AnnAGNPS on Mississippi Delta MSEA watershed. Transaction of ASABE 44, 1183-1190.

Yuan, Y., Locke, M.A., Bingner, R.L., 2008. Annualized agricultural non-point source model application for Mississippi Delta Beasley Lake watershed conservation practices assessment. J. Soil Water Conserv. 63, 542-551.

Wischmeier, W.H., Smith, D.D., 1978. Predicting rainfall erosion losses-a guide to conservation planning. U.S. Department of Agriculture, Agriculture. Handbook No. 537. U.S. Government Printing Office, Washington, DC.
Zema, D.A., Bingner, R.L., Denisi, P., Govers, G., Licciardello, F., Zimbone, S.M., 2012. Evaluation of runoff, peak flow and sediment yield for events simulated by the AnnAGNPS model in a Belgian agricultural watershed. Land Degrad. Dev. 23 205-215.

Zema, D.A., Denisi, P., Encarnación, V., Ruiz, T., Gómez, J.A., Bombino, G., Fortugno, D., 2016. Evaluation of surface runoff prediction by AnnAGNPS model in a large Mediterranean watershed covered by olive groves. Land Degrad. Dev. 27 (3), 811-822.

Zimmerman, R., Schulze, E.D., Wirth, C., Schulze, E.D., McDonald, K.C., Vygodskaya, N.N., Ziegler, W., 2000. Canopy transpiration in a chronosequence of Central Siberian pine forests. Glob. Chang. Biol. 6, 25-37. 